\title{
BIBLICAL AND RELIGIOUS STUDIES - CONTINUOUSLY COMMITTED TO THOROUGH TRANSFORMATION
}

\author{
Jannie Malan \\ Emeritus Professor of Biblical and Religious Studies \\ University of the Western Cape
}

\begin{abstract}
The doctrinally unprejudiced exploring of Old and New Testament genres and texts has led, and can still lead, to contextual insights with most significant implications. A content-based interpretation is transformed into a dynamic understanding which recognises relational believing in the events out of which the various writings originated and in the meanings communicated by each of them. The widelyproclaimed message of accepting forgiveness by faith in Christ and then gratefully obeying ethical instructions is transformed into Jesus' original and unique Good News of an inner change of mind and life, in which both forgiveness and deliverance are effortless realities. Christians who believe and live this message do not only experience transformed living themselves, but, as they co-exist with fellow-humans in a diverse country and world, they may also contribute to the transformation of unjust structures and divisive attitudes. All of us who are committed to such a Biblical and Religious Studies approach should therefore not be disheartened by phased out educational privileges, but should continue utilising every opportunity of furthering and disseminating the message of inner transformation.
\end{abstract}

\section{Introduction}

I would like to address a comprehensive and challenging theme in this article: "The Bible, empowerment and flexibility: About being a transformational Christian in a diverse world". Our attention is drawn to the treasured Scripture of Judaism and Christianity of which we are devoted students, and to the dynamic of its message in our contemporary world. We are called to promote the sharing of the timeless Good News of transformation in today's world of religio-cultural diversity. But the real thrust of our theme is to highlight the essential importance of being transformational Christians where we happen to co-exist with our fellow human beings on this planet in the universe.

In line with this topical theme I wish to share a few thoughts as an appraisal of the way in which our field of study may constantly be promoting genuine Christian believing and living among fellow South Africans (and global citizens) with various religious convictions.

I am convinced that as a tertiary ${ }^{1}$ and also secondary ${ }^{2}$ field of study, Biblical Studies, and more recently Biblical and Religious Studies, has - to a large extent at least - fulfilled a pronounced transformative function, and that it deserves all possible support to continue in this way. By inserting the "to a large extent" phrase in the previous sentence, I am

1. Introduced in 1954 at the Potchefstroom University for Christian Higher Education. At tertiary level our South African Biblical Studies has comprised much more than the German "Bibelkunde" which was mostly confined to brief, popular introductions to biblical books (cf Gutbrod 1973).

2. First introduced in 1969 as a stds 9-10 (grades 11-12) school subject in its own right (distinguished from Religious Education) in schools for whites in the then Transvaal Province (Duvenage 1974:1). 
admitting the unfortunate reality that not all the designers, teachers and learners in our field of study have been, or are currently, working in this transformative way. In fact, the initiators of Biblical Studies as a school subject apparently had rather conservative objectives (cf Duvenage 1974:1). And to our day, in a renewed and renewing South Africa, there are still many well-intentioned custodians of an outdated status quo.

The first transformational influence I wish to highlight is that with regard to the understanding of the Bible.

\section{Transforming the understanding of the Bible}

You may surely ask why I attribute a transformed understanding of the Bible to Biblical and Religious Studies and not to Christian Theology in general. After all, as a particular subject in secondary and tertiary education, Biblical (and Religious) Studies has a very short history of only a few decades. And during the almost 20 centuries of Christian biblical interpretation significant insights have indeed been reached by hermeneutical searchers and researchers who were working under the banner of theology. Such observations are of course valid, but there happens to be something else that also has to be borne in mind: the problem of all the status quo understandings of the Bible that have become established in Christian Theology and have been deliberately fortified against any "onslaught" of transformation. ${ }^{3}$

The wide and extremely complicated field of Christian Theology is therefore one in which decisive distinctions may (or should) be responsibly discerned and implemented. A particular distinction that may be applied with regard to our topic of transformation is the one between an authoritarian dogmatism (to which so many theologians have unfortunately been prone through the centuries) and a relational fideism ${ }^{4}$ (which I tend to regard as a precursor of a genuine Biblical and Religious Studies approach). In an attempt to explain something of my way of thinking, I wish to share a few historical and a few personal comments.

From the very beginning of Christianity a far-reaching differentiation (that had already been noticeable in Old Testament times) became crucial. In an attempt to describe and discuss this distinction two Latin phrases were coined later, and may still be helpful. The one, fides qua creditur, ${ }^{5}$ tries to put believing as an event into words. The other, fides quae creditur, ${ }^{6}$ points to the content which is accepted in faith. It was in a context of pious, dutiful effort to observe (the content of) God's commandments (plus numerous addenda by men bent on studying ancient texts) that Jesus exemplified and proclaimed (the event of) an inner change of mind and life that can be brought about by God's grace. ${ }^{7}$ It was as one delivered from the Pharisaic context that Paul wrote about his convictions and recommendations. What therefore seems to have been predominant in the 1 st century of the Christian era, was a pioneering focus on a faith relationship. When in the 2 nd century,

3. Du Toit (2000:173) deplores the fact that recent (modern and post-modern) insights into the nature of the original biblical texts have (for many years!) only been recognised in the bibliological subjects of theological study, and have not been integrated with systematic thought on doctrinal matters.

4. Or, in English, faithism. I use an "-ism" term to acknowledge that proponents of approaches in which faith is taken seriously have in many situations gone to unfortunate and counter-productive extremes.

5. Literally, "faith through which is believed", or, adding the definite article and omitting the awkward passive voice, "the faith through which one believes" (Stewart 1980:18). Paraphrased as follows by Deist (1984:61b): "the act of faith leading to faith, i.e. the ground or foundation of faith..."

6. Literally, "the faith which is believed" (Stewart 1980:18). Paraphrased as follows by Deist (1984:61b): "the contents of faith, i.e. ecclesiastical tradition".

7. Cf Jn 5:39-40. 
however, disunity threatened in the Christian community, an understandable refuge was sought in the canonisation of texts and the formation of doctrine (Rossouw 1963:20-24). Faith became reified into a revered object. Terms such as regula fidei ${ }^{8}$ were used, and dogmatic decisions of the ecclesiastic concilia of the 4th and 5th centuries were called leges fidei $^{9}$ (Rossouw 1963:29,38)! The preoccupation with the content of faith led to the prolonged christological dispute and its hermeneutical side-effects. ${ }^{10}$

During the Middle Ages "orthodox" doctrinalism wielded great power, as reflected by a prescription as the following: "Learn first what you should believe, and then go to the Bible to find it there" (Berkhof 1967:23). ${ }^{11}$ Even so, a doctrinally unprejudiced study of biblical passages and books in their historical context somehow managed to survive through medieval scholasticism. It made a promising come-back during the 16th century reformation, ${ }^{12}$ but before long a new orthodoxy gained the upper hand in the Protestant world and precipitated a preoccupation with "reformed" doctrine. ${ }^{13}$ In the 19th century historical and literary research ventured courageously into the origins of the first books of both the Old and the New Testament. But when findings that threatened traditional certainties were publicised, historical criticism became branded as irreverent and almost heretical. ${ }^{14}$

My personal comments are, briefly, the following. I grew up in a pre-Biblical Studies era when a fairly authoritative exegetical tradition was communicated through Sunday School teaching and Sunday after Sunday preaching. A striking, if not shocking, example of this approach was the method of "teaching" exegesis to post-graduate students at theological seminary. For four years we were faithfully writing down dictated notes on the

8. Rule of faith.

9. Laws of faith

10. The victory of the Alexandrian fathers favoured the Alexandrian school of allegorical exegesis, and the defeat of the theologians of Antioch brought the Antiochene school of progressive grammatico-historical interpretation into disrepute (Rossouw 1963:75-76).

11. A quotation from Hugo of St Victor. Such a procedure of eclectically using the Bible to endorse one's own viewpoints is still a temptation to all of us, of course! Cf Barr's (1987:3) admission: “...I became convinced that we who claimed to regard the Bible so highly were really not listening to it. Though we accused others of neglecting the Bible, we insisted that it always say what we had predetermined it would".

12. A striking encouragement towards contextual exploring was given by Myles Coverdale who (early in the 16th century) undertook the then life-threatening risk of translating the Bible from elite Latin into understandable English:

"Myles Coverdale, in his translation in speaking of the Bible, writes:

'It shall greatly help ye to understand Scripture if thou mark

not only what is spoken or wryten,

but of whom

and to whom

with what words,

at what time,

where,

to what intent,

with what circumstances,

considering what goeth before

and what followeth" (Marsh 1960:xiii).

13. According to Brunner (1925:113) Calvin focused almost exclusively on the fides quae creditur, the object of faith.

14. Cf the verdicts imposed by an "orthodox" establishment on Bishop John Colenso and Prof Johannes du Plessis, and in the 20th century also the grave warnings against Rudolf Bultmann's propagation of demythologising. 
recommended exegesis of substantial parts of the Old and the New Testament! ${ }^{15}$ One of the most extreme manifestations of such traditional exegesis - which allowed itself to be contaminated by a particular (also traditional!) socio-political ideology - was the utilising of convenient bits from the Old Testament as a divine validation of apartheid theology.

I did have a sampling, however, of what would later be an important part of Biblical Studies. This happened in my undergraduate study (in Arts faculty) of Greek, Hebrew and Latin, where, as a side-line, some interesting details were studied about the daily life of the then people who used these languages. I found this background study of Palestinian geography and archaeology and of Judaic, Hellenistic and Roman culture very interesting and illuminating.

The search for an honestly contextual understanding of the varied genres and writings preserved in the Old and the New Testament ${ }^{16}$ has indeed become a crucial part of what I call a Biblical Studies approach. The contexts are explored in which people were living, thinking and communicating at the various stages of about two millennia during which the various parts of the Bible came into being. ${ }^{17}$ This approach can open up surprising views into ancient situations in which real women and men, girls and boys, had actual experiences in the dimension of believing. ${ }^{18}$ It can manage to penetrate metaphors, symbols and prescientific and/or cultural perspectives, and approach the dynamic and meaningful core of each faith experience (Cf Van Huyssteen 1986:168). And it can invite present-day readers of those written records to experience the thrill of a faith relationship and the miracle of an inner transformation (cf Sangster 1957:173-177).

It is this orientation towards believing as a relational event (fides qua...) that can serve as an urgently needed safeguard against firmly entrenched practices as the following:

- Employing a particular paradigm, for instance from the 4th, 16th or 20th century, as hermeneutical tool and rule in our current situation

- Juxtaposing ${ }^{19}$ texts from totally different parts of the Bible - for instance, lawobservance Old Testament sections and conversion-faith New Testament sections to substantiate doctrinal theses ${ }^{20}$

Moreover, the faith approach may point to a way out of a debilitating predicament in which many genuine Christian believers who happen to have content of faith (fides quae...) strings attached to them find themselves. Undoubtedly there are believers who have discovered the life-transforming essence of the Christian message ${ }^{21}$ and are experiencing such a transformed life, but find themselves in situations where they may not say anything

15. There was one exception, however. One single period in the four years was devoted, in response to an urgent request from the students, to guidelines for practising one's own exegesis!

16. Cf: "The great strength of the historical method... has been to free us from the tyranny of the present by showing us the past... The major advantage of social analysis methods is that they bring to life the real world of social interaction in which early believers heard these texts" (Barr 1987:4).

17. Kee \& Young 1987 may serve as a good example of a study in contextual understanding. And, interestingly enough, this dual significance is highlighted by the titles of the UK and the USA editions, respectively: The Living World of the New Testament and Understanding the New Testament. Another good example of this approach is Grollenberg 1979.

18. "To enter the thought world of the people who produced the Bible, we must study the life situations in which their convictions came to them, and out of which they responded to those convictions" (Kee \& Young 1987:vii).

19. In spite of the fact that what is called "the history of revelation" is taken into account!

20. Cf, for instance, Heidelberg Catechism, answers 5, 9.

21. As communicated by, for instance, Mt 3:17, 22:37-39, Mk 10:42-43, Lk 24:47, Jn 3:3, 13:35, Rom 6:13-14, 7:6, 12:1-2, 1 Cor 10:13, 2 Cor 5:17, Gal 5:25, Eph 4:23-24, Col 3:10, 1 Jn 2:29. 
against a preoccupation with the content of faith and an accompanying cynicism about the reality of a changed way of living. Where such believers do not take their membership of a church seriously, they may indeed share their insight and experience, and take any resulting ostracising in their stride. But if they are ordained ministers, they may have to keep quiet or face excommunication. Or they may (for the time being?) take refuge in the in between option of camouflaging their decoding of ancient metaphors and symbols under impressive circumlocutions. By means of sophisticated wording and phrasing they may venture quite close to honest breakthroughs, but usually their own ministerial position and the peace of the church $^{22}$ will cause them to stop short of unambiguous statements.

It is out of such a doctrinocratically guarded captivity that a genuine commitment to believing as a relational event (fides qua...) might hopefully supply an escape route. In a non-defending and non-prescribing, but precisely in a bona fide way, transformed and transformative insights as the following may be frankly shared:

- The dimension in which voices and visions, dreams and revelations, convictions and persuasions - as far as they were authentic, at least ${ }^{23}$ - were received and internalised was, inevitably, the dimension of believing.

- People who had had such experiences, must have felt the inner urge to share as much as possible with others, but they could obviously not share the unique event itself. They therefore had to encode the meaning into something they could communicate - a story or a poem, an allegory or a myth, a song or a prayer, a ceremony or a sacrament, an inscription or a book.

- The interested or even fascinated receivers of such communications basically had three options. They could decode the message and then focus all their attention on the essential fides qua meaning. Or they could become absorbed in the code itself and begin using it as the foundation for a fides quae structure. Or they could understand the meaning and appreciate the code (Malan 1999:7-10, cf Grollenberg 1979:111-116, Morris 1986:15,333, Du Toit 2000:60-61).

- It is especially this third option that can lead to what I am calling a Biblical and Religious Studies understanding of the Bible. ${ }^{24}$ In this kind of approach the historical situation and the religio-cultural context of the original event and communication are explored and taken into consideration. In an unprejudiced and honest search for meaning any context-bound symbolic, idiomatic or cryptographic elements that may be discernible are decodingly penetrated (cf Streeter 1936:123, Du Toit 2000:79-80). In an always modest but usually enthusiastic way the apparent significance can then be identified and communicated (Du Toit 2000:117). Where appropriate the necessary distinction can be made between meaning then, meaning now and/or possible meaning for all time.

22. Cf Smart 1970:67, with regard to theological schools protecting their students against the findings of historical criticism: "But the peace of the church was valued more highly than truth. The consequences of leaving a twentieth-century church with a seventeenth-century mind were ignored."

23. There has always been, and will always be, the possibility of faked "religious" experiences. In an area where there is no way of proving the authenticity of such an event, either when it happens or afterwards (after millennia, for instance), this unnerving possibility is unfortunately constantly available for deceitful misuse.

24. It was in an award-winning book (1987 Andrew Murray prize) with a theological title that a Biblical Studies professor emphasised (my translation): "The way in which the theologian as Christian believer experiences his or her faith and the nature of the resulting language of faith, is eventually codetermining for both the theological and the scientific-philosophical status of theological statements" (Van Huyssteen 1986:154). 
I am therefore suggesting that we keep endorsing and promoting the Biblical Studies from-faith-to-faith procedure, where the point of departure is one of thinking ourselves into original experiences of faith, and where the outcome can be at least an insight into, but possibly also a real experience of, transformed living in a faith relationship with God.

\section{Transforming the self-assuredness of one-track minded 'theology'}

The orientation to relational believing, instead of to a reified faith, is one that inevitably takes relationships seriously, including those with adherents of denominational doctrinal persuasions. Relational believers will therefore refrain from disparagingly criticising the traditional tenets of fellow-Christians or fellow-humans of other religious convictions. Precisely on account of their contextual perspective they will - understandingly, and sympathetically where necessary - take the background of content believers into account. This background will obviously differ from group to group and from individual to individual, but very often its core elements may be a well-intentioned indoctrination according to a particular confession of faith, and an equally well-intentioned and therefore unquestioning commitment to the "truths of faith" concerned.

At the same time, however, genuinely believing believers have every reason to live and communicate the message of mind- and life-transforming faith. Their irresistible inner urge may therefore be to share their own breakthrough experiences with everyone who is still wholeheartedly clinging to literally accepted truths of faith. But their way of witnessing will usually not be based on a mutually exclusive dichotomy between the doctrinally lost and the doctrinally saved. If their whole way of thinking and living is based on believing in an integrated fides qua and fides quae mode - they will be radiating and communicating the inclusive reality of relational believing.

Such a dynamic message is dimensionally different from one of prescriptive proselytising. It spreads its transformative influence in non-contending and non-defending ways. As it was said of Archbishop Desmond Tutu that he killed apartheid with love, ${ }^{25}$ it may be said here that real believers may help to eradicate doctrinal exclusivism with loving understanding.

Precisely because the Biblical and Religious Studies approach is one that transcends the boundaries of fixed formulas, this propagation of believing will not be conveyed by stereotyped phraseology or methodology. As Jesus varied his sayings and parables according to situations and audiences, today's believers may use their communication skills in surprisingly creative ways. One of these may be the disseminating of modest but potent seed questions, of which some may land in the fenced-in fields of one-track minded orthodoxies.

The question may for instance be asked whether it is only the parts of the Bible that have to be interpreted contextually, or perhaps also the theological documents from the past. ${ }^{26}$ Is it not self-evidently important to understand the circumstantial and/or cultural context in which a confession of faith was formulated? Or in which a theological treatise was written? And is it not crucially important to distinguish between reactions to timebound matters and commitments to all-time issues? Is it not so that believers of later periods are justified to distinguish between elements of restricted, synchronic relevance and core parts of limitless, diachronic significance (cf Grollenberg 1979:2)?

25. Obviously not a weak, submissive love, but an energetic, assertive love.

26. Cf Van Huyssteen 1986:155 about how the socio-cultural contextuality of all models of thinking deepens the question about the origins of confessional and theological statements. Cf also Van Huyssteen 1986:196 and Ehrman \& Holmes 1995:361-362. 
Contextual questions may then also be posed about the identification of such core parts. What, for instance, could be the backgrounds and motivations behind formulations of what is conceived as the core message of the New Testament? To what extent have they been ecclesiastically, or even denominationally, influenced? ${ }^{27}$ To what insights could unprejudiced, contextual New Testament study lead $?^{28}$ May the following be regarded as a very good example of the results of such an approach?

- The acknowledgement that "the whole of the New Testament is informed by a common conviction regarding the redemptive significance of Jesus" (Kee \& Young 1987:54), but also an understanding of the Jewish Christian-friendly as well as the non-Jew-friendly elements in the kerygma.

- The resulting insights that it was "in keeping with Hebrew tradition ${ }^{29}$ that the sacrificial significance of Jesus should be a major theme in the preaching of the early community" (Kee \& Young 1987:59) and that it was in response to the interests and needs of the non-Jewish peoples that a special emphasis was placed on "the belief...that Jesus death and resurrection accomplished the defeat of the evil powers" (Kee \& Young 1987:255).

- The highlighting of what was really crucial in Jesus' message: "His purpose was to make perfectly clear that the new life was to be lived not in a relationship to laws but to the living God - a person - and to one's fellow man" (Kee \& Young 1987:132, cf Grollenberg 1979:38).

And then there are the frank and penetrating questions that may and should be asked about metaphors and symbols. Is it not a matter of double standards when metaphors in general literature are interpreted metaphorically, but those in religious literature are taken literally? Is it not so that metaphors and symbols are inevitable and almost essential components of the language of faith $?^{30}$ Are they not used as (exactly as!) non-literal ways of communicating ineffable aspects of experiences and relationships in the dimension of faith? And whenever a metaphor is rigidified into sacrosanct literalness, could the effect not be (in spite of the best intentions) that its dynamic meaning gets sidelined or even lost?

At this point, which fides quae believers often regard as the watershed between belief and unbelief, I wish to re-emphasise the non-iconoclastic, but relationship-building and faith-promoting nature of the Biblical and Religious Studies approach I am propagating. From the panoramic viewpoint of a watershed, if I may add-on another thought to this metaphor, a comprehensive overview over open spaces and entrenched valleys may be obtained. But then more attention may be devoted to the variety and interrelatedness of the

27. In spite of my agreement with the main thrust of Du Toit 2000, I cannot help discerning some possible promptings by established confessions of faith when (my translation) "the core of the Christian faith" is defined as "The merciful forgiveness of sins through the crucifixion of Jesus of Nazareth" (Du Toit 2000:146, cf 160,181).

28. Could it not have been the Biblical Studies route that led Van Huyssteen (1986:167) to point to "deliverance in Jesus Christ" as "the original metaphor of our Christian faith"? (my translation of "verlossing in Jesus Christus" and "die grondmetafoor van ons Christelike geloof") These words introduce a long sentence, which outlines the development of this core belief out of complex biblical language, through a long tradition of Christian reflection, to theological concepts that are eventually accessible to believers and believing worshippers.

29. In which "sacrifice was essential to the establishment and maintenance of fellowship with God" (Kee \& Young 1987:59).

30. Cf Berger (1988) on metaphors as commonplace (and not at all just a rhetorical addition) in everyday language and religious language. 
topography than to the dividing line of the watershed. So, in a discussion about biblical metaphors, wide and deep insights as the following may be shared:

- Self-evident metaphors are usually common-sensically understood as metaphors. Everyone will probably accept Jesus' saying "I am the gate" (Jn 10:7,9) as meaning that he provides an entrance.

- Apocalyptic symbols are probably understood by most, or at least by many, as images occurring in visions of future scenarios. Everyone who has been introduced to the apocalyptic idiom will therefore decode (for instance) the trumpets, thrones and seals of the book of Revelation as ceremonial announcements, highest authorities, and information-guarding measures.

- If anyone refuses, however, to interpret Revelation (and also Jesus' "prophetic discourse", Mt 24-25, Mk 13) apocalyptically, no one can prevent him/her from faithfully (!) adhering to literalism. Nevertheless, however, two urgent appeals may be made to such a literalist. He/she may firstly be beseeched to allow others to adhere to their (bona fide!) interpretations, even if these are diametrically different from the literal extreme. And, secondly, he/she may be implored to consider the possibility that such a decoding may be undertaken precisely with the objective of uncovering the meanings which the symbols were meant to convey.

- What some believers, who are honestly and fearlessly searching for deepest meanings, may regard as kerygmatic metaphors or symbols, may include some of the concepts that are meticulously cherished by doctrinally brought up believers as non-discussable truths. A good example is the ascension of Jesus. ${ }^{31}$ Here too, in the absence of any proof to confirm it either as a fact or as a symbol, interpretational freedom may be granted. Those who firmly believe that it happened as described may continue doing so. And those who believe that it was proclaimed as a symbol of divine approval, in the days when heaven and celestial beings were perceived to exist above a flat earth, may stick to their conviction. But in this case too, serious appeals may be made - to believers at both extremes and in between - to practise tolerance and to penetrate through peripheral issues towards core meanings.

Questions, thoughts and insights, as the few examples briefly outlined above, may indeed lead to fruitful discussions around credos $^{32}$ (which usually are actually credamuses $^{33}$ ) within the field of Christian theology. ${ }^{34}$ But their discussion-prompting dynamic may also be extended to the field of dialogue with fellow-humans of other faiths.

Since the scope of our subject has been extended to include Religious Studies, a special emphasis has been placed on the faith-enriching possibility of an open-minded conversation with people of other religious convictions. Time and again findings show that such dialogue usually has no detrimental effect on the faith relationships of the participants. On the contrary, it can enhance the quality of their faith and increase their commitment to their own convictions.

31. Cf also Ehrman 1993:72,75 on Mk 1:1.

32. "I believe" statements.

33. "We believe" statements.

34. Cf Ehrman's (1993:275) thesis: "proto-orthodox scribes of the second and third centuries occasionally modified their texts of Scripture in order to make them coincide more closely with the christological views embraced by their party that would seal its victory at Nicea and Chalcedon". 


\section{Transforming the way of thinking and living of legalistically indoctrinated Christian church members}

One of the greatest advantages of what I call the Biblical Studies approach, in which insights revealed by contextual exploration are courageously accepted, is that it highlights the distinction between law observance as an imposed duty and inner transformation as a spiritual reality. More than that, it emphasises the unequivocal orientation of Jesus to this inner transformation.

What I have already quoted above, as a good example of a Biblical Studies finding, deserves repeated emphasis here: Jesus' "purpose was to make perfectly clear that the new life was to be lived not in a relationship to laws but to the living God... and to one's fellow man" (Kee \& Young 1987:132).

Is it not this purpose and message of Jesus that account for the essential newness of the New Testament? Was the epoch-making significance of Jesus' coming not adequately stressed at several places in the New Testament? At the beginning of the gospel according to John (1:17) we read, for instance:

God gave the Law through Moses, but grace and truth came through Jesus Christ.

And in Paul's letter to the Galatians (3:24-25):

And so the Law was in charge of us until Christ came, in order that we might then be put right with God through faith. Now that the time for faith is here, the Law is no longer in charge of us. ${ }^{35}$

The anomaly is, however, that Christian believers who are taking this crucial insight seriously seem to be the exception! And the tragedy is that the majority, who are apparently oblivious of this paradigm switch, keep living and witnessing on the non-Christian wavelength of trying one's best to obey moral laws. Without realising what they are actually doing, they are in effect denying Jesus and taking the side of the legalistic law venerators who vehemently opposed and eventually crucified Jesus!

I am open to criticism and ready for discussion, but my internalising of Jesus' message of inner transformation (as for example handed down to us in Mk 1:15 and Jn 3: 3-16) obliges me to avoid and to counteract as far as possible all traces of legalistic language in the communication of our "Good News". ${ }^{36}$

So, for instance, my unavoidable reaction to a Christian sermon or publication in which the "effort error" is committed, is to think (and say if possible) that it is a pathetic deviation from Christian language and from the Christian way of thinking.

What I term the "effort error" is strikingly exposed by the two questions in Gal 3:3:

How can you be so foolish! You began by God's Spirit; do you now want to finish by your own power?

Present-day examples of this error are unfortunately abundant. How many exegetically and theologically well-prepared sermons do not end, for instance, in the anti-climax of a grace-renouncing appeal, such as "Try your best to apply this message in your daily life this week"?

35. Cf also: "the new covenant...consists not of a written law but of the Spirit" (2 Cor 3:6) and "No longer do we serve in the old way of a written law, but in the new way of the Spirit" (Rom 7:6).

36. Ethical guidelines may of course be given in a non-legalistic way. In Rom 12:9-21 and Eph 4:25-5:5, for instance, the context of inner change is unequivocally clear from Rom 12:1-2 and Eph 4:23-24, respectively. 
To me it seems to be glaringly self-evident that such a resigning of oneself to an ongoing struggle towards self-improvement is the exact opposite of what Paul singled out as the essence of Christian worship (Rom 12:1-2):

Offer yourselves as a living sacrifice to God ... let God transform you inwardly by a complete change of your mind. ${ }^{37}$

This, to my mind, is the genuinely Christian message that has to be proclaimed. And believers who have acquired insights as outlined above are indeed equipped, liberated and called to perform a crucial function in this regard.

To confront and counteract the law-duty-effort mindset is no easy task, however. After all, this way of thinking and preaching is widely popular and deeply rooted. Its defence mechanisms are well developed. There is a typical argument, for instance, by which the invitation to a change of mind and life (Rom 12:2) is deprived of its meaning and power. In this argument, Rom 7 is read according to the concept of an inherited and inherent sinfulness, which is so "original" that it overrides the grace of God. Then the exclamation about being an "unhappy" habitual sinner (Rom 7:24) is regarded as the last word, in spite of the expression of thanks to God for deliverance through Jesus Christ (Rom 7:25a). But an unprejudiced Biblical Studies type of contextual, and here especially also textual, study can bring one to an obvious understanding as the following. Paul did use "I" language in Rom 7:14-24 and 25b, but only to form a striking contrast with the "God" language of Rom 7:25a, 8:4, 13 and 7:6. Then the conclusion is no longer the pessimistic one of resigning ourselves to a never-ending struggle with $\sin$ (Rom 7:25b). It becomes the positive one of gratefully accepting the amazing reality of deliverance by God's grace (Rom 7:25a) ${ }^{38}$ And the last sentence of Rom 7:25b is then understood as a final contrast with the frustrating limitations of the human I on his/her own. The validity of this interpretation is clearly vindicated by the passage which follows immediately:

...the law of the Spirit, which brings us life in union with Christ Jesus, has set me free from the law of sin and death. What the Law could not do, because human nature was weak, God did... Those who live as their human nature tells them to, have their minds controlled by what human nature wants. Those who live as the Spirit tells them to, have their minds controlled by what the Spirit wants (Rom 8:2,3a,5).

An outspoken emphasis on this faith-oriented (instead of effort-oriented) way of thinking and living is found in Christian literature, but not nearly as pervasively as could have been expected. For example (my translation):

And just look at the genuinely converted human being: obedience comes spontaneously. His/her good actions emerge from the sources of love as fresh water bubbles up from the underground source without trouble or effort... Spontaneously, or with effort, there lies the touchstone ${ }^{39}$ (Knap 1935:109-110).

Shouldn't the lone voices endorsing the anti-legalistic and anti-self-effort message of Jesus become more numerous and more assertive? Shouldn't all of us who are committed to the Biblical and Religious Studies approach keep highlighting Jesus' proclamation of a transformation of mind and life, which is of nothing less than metanoia quality?

37. See also Gal 5:16, Phil 2:13 and 1 Jn 5:4, 18, and cf Sangster 1957:46.

38. Cf 1 Cor 10:12, 1 Jn 5:18.

39. To drive home this point this author also used the metaphor of an oil lamp that radiates its light spontaneously and silently, in contrast to a pressure lantern, of which the bright (and noisy!) light gradually gets dimmer, and which therefore needs regular pumping (Knap 1935:110). 


\section{Transforming the co-existence of diverse groups and individuals in a dual- gendered and multi-cultural community}

The transformative role that Biblical and Religious Studies can play is not confined to the areas of hermeneutical debates and spiritual experiences. The three aspects outlined above can have far-reaching consequences in everyday life.

As a first example we can look at a transformed way of living up to the missionary calling of Christianity.

When the surface structure of Biblical books and theological documents is understood in terms of their underlying meanings, nothing less than a paradigm shift can take place in the way in which the Christian faith is communicated and promoted. What I have already said in this regard may be outlined as follows:

- Believing is accepted as the obvious context which is relevant in interpreting, internalising and sharing the Christian message. It is a matter of believing that experiences in the dimension of believing gave rise to narratives, poems, instructions, symbols and customs which were faithfully received and recorded by fellow-believers. And that it was in faith that such elements were handed down through periods of oral and/or written tradition.

- The relational and internal dynamics of believing are therefore always much more important than the contents or structures by means of which inner meanings are communicated to others and transmitted to succeeding generations. Some of these meanings were self-evidently only of ephemeral significance in particular situations. Others were of longer-term relevance, and some may duly be regarded as retaining their life-transforming meaning for all time.

- The most effective way in which such a message may be shared with others is one of living the transformed lifestyle and talking about the change of mind. When witnessing takes place on the wavelength of believing, any attempt to defend or prove dogmas or "truths of faith" will obviously be avoided. And when the receivers of such a faith message are committed to another faith or to agnosticism, an open-minded discussion may prove more fruitful than narrow-minded argumentation.

- A transformed way of living in which the actual practising of justice and love is a spontaneous reality, and not an ideal striven after with mixed degrees of success, surely has an appeal that may be unique in the entire dimension of religion.

Believers who have internalised a relational, life-renewing faith (Jn 3:3,15,16,21, Mt $22: 37-38,{ }^{40}$ Rom 12:1-2) and have been liberated from duty-bound efforts to comply with moral laws (Gal 5:1,4), and are therefore radiating a modest but dynamic and inclusive attitude (Phil 2:1-11), are automatically doing what is envisaged in 1 Pet 3:15-16:

Be ready at all times to answer anyone who asks you to explain the hope you have in you, but do it with gentleness and respect.

The core message of Christian believing indeed deserves to be communicated in such an atmosphere of honest dialogue and mutual respect, while it is endorsed by the lifestyle of the communicator (cf 1 Pet 3:2).

It may of course be said that the spreading of Christianity throughout the long history of Christian missions probably took place mainly by proclaiming the orthodox content of

40. In his answer Jesus repeated the teacher of the Law's word "commandment", but used it in a different semantic field. 
Christian theology (fides quae). From the Biblical Studies perspective a few more things may also be said, however. It should be remembered that what the missionary history largely deals with is the growth of nominal Christianity. The achievements of well-meant missionary methods may be appreciated, ${ }^{41}$ but what should constantly be promoted and practised are ways of recommending a relational (fides qua) faith of metanoia quality and reality. $^{42}$

Such a message, communicated with such an attitude, and validated by the lifestyle of those who communicate it, is very much in place in our new, multi-faith South Africa. It can contribute to mutual understanding and respect between people committed to a diversity of convictions. At the same time, it can play a significant role in debates between religious believers ${ }^{43}$ and scientifically minded questioners. And above all, it can disseminate the Christian "Good News" of inner change (instead of dutiful striving), which could very well be the only message of its kind among all religions.

As a second example we can take the impact and influence of simply being transformational Christians ${ }^{44}$ in our daily life among fellow human beings.

As traditionally brought up Christians, we may perhaps be inclined to underestimate the importance of our everyday existence with all its domestic chores, routine tasks, workplace responsibilities and recreational diversions. We may have been religiously educated into having a high regard for special occasions of worshipping, jointly and individually, but being a bit less concerned about commonplace, mundane activities. Of course, we do accept the secular scene as the environment where we can show our justice and love to others and practise the applications of sermons and personal Bible study. But then our special orientation may still be towards the elevated moments of witnessing through deed and word.

Actually being a transformational Christian, however, means experiencing a radically different way of being there. You do not think in terms of showing justice and love, or applying what you have heard in church or have read in the Bible. You are spontaneously motivated by metanoia thinking and spontaneously energised by metanoia living (cf Sangster 1957:62-63).

Moreover, this miracle of grace does not only take place in comfortable surroundings between like-minded believers or look-alike and same-culture people. It can also be a stimulating reality in the challenging circumstances of co-existing with fellow-humans of different physical features and/or cultural customs and/or socio-economic conditions.

What is very important to remember, however, is that it is especially in a situation of diversity that the spontaneousness of transformed living can make a crucial difference. Our general sensitivity to the attitudes of others usually enables us to discern between a show of friendliness and genuine friendliness. But when the others happen to be different in appearance, language or cultural behaviour, this sensitivity tends to become still more acute. Signs of pretence and insincerity do not go unnoticed. Effort-based niceness may be decently endured, but the receivers will fathom the fallacy. But a natural, inwardly motivated attitude of fellow-human interest and co-existence is sensed equally well. Such

41. Did Paul not perhaps fall back into mere content of faith thinking when he connived at wrongly motivated ways of preaching Christ (Phil 1:15-18)?

42. If I may add $m y$ personal note (which happens to differ from Paul's!), I wish to say how grateful I am that when I worked as "missionary" in the Dutch Reformed Church in Africa (1957-1958, 1966-1972), I already had acquired most of the Biblical Studies insights discussed above.

43. With all their diversity: content believers, event believers, and those who integrate the two approaches.

44. Cf my initial emphasis ( 1 above) on the second part of the theme for this meeting. 
an attitude and the behaviour spontaneously flowing from it may probably do more than anything else to break through and remove cross-cultural and cross-racial barriers. In our new South Africa, where diversity provides challenges and opportunities around every corner, this orientation can therefore contribute greatly to a climate of diversity-transcending relationship building.

What is highlighted by the Biblical Studies approach, is not only the spontaneousness of transformed living, however. By means of the distinction between meaning then and meaning now it shows where cultural concepts of biblical times and places have to be replaced by insights and responsibilities of our current context.

The Biblical Studies perspective cannot just focus, for instance, on a meek lovingkindness in a religious and/or spiritual context. ${ }^{45}$ Wherever appropriate, it may include all the necessary frankness about socio-economic, political or cultural injustice, and all the required insistence on the rectification of wrongs. It will honestly face and counteract stereotyping and prejudice. It will allow and promote mutual assertiveness - otherassertiveness and self-assertiveness.

Very particularly, this approach cannot but place an unrelenting emphasis on gender assertiveness. With shame and apologies, it exposes the hermeneutical fallacy which made Christianity elevate the ancient favouring of men to a non-negotiable ruling. With fearless courage, it reinterprets passages as Eph 5:22-24 and 1 Cor 14:34-35 (cf Ehrman 1995:367), and with acclamation it affirms Luke's women-friendly universalism as discernible, for instance, in Lk 7:37-8:3.

About being transformational Christians in a new South Africa in a new millennium much more can be said, but little more has to be said. Where an inner change of mind and life has taken place, there is no real need for guidelines or suggestions. It is mainly a matter of responding to the inner urge of doing something towards transforming unjust structures and divisive attitudes. And since this inner dynamic is no human effort, it never becomes enervated by disappointments. It harbours no illusions about general co-operation to change structures and attitudes. It does not seek recognition of successful achievements. It is not dependent upon reminders about religious or moralistic duties. It simply remains committed to promoting intra-human and inter-human transformation as a never-ending opportunity and privilege.

There happens to be a severe disappointment of a different kind, however, which we have to deal with. As a secondary and tertiary field of academic study, Biblical and Religious Studies is being phased out! ${ }^{46}$

If we apply our skills of contextual insight and relational sensitivity, we can understand why this is taking place. In the new South Africa, we are no longer in a more or less Christian state, which metes out preferential treatment to Christian institutions. We have a Constitution which rules out unfair discrimination on grounds of "race, gender, ...ethnic or social origin, ...religion, ...belief, culture..." (Constitutional Assembly 1996:art 9(3)) and an Educational system where "everyone has the right...to a basic education" (Constitutional Assembly 1996:art 29(1)), but where independent educational institutions are also accommodated.

45. Speaking about true happiness (Mt 5:3-12), Jesus did not only emphasise peace and love (Mt 5:9,7) but also justice (Mt 5:6,10).

46. Five years ago there were still other possibilities (cf Malan 1997a and 1997b). Unfortunately, however, refuge was apparently taken to negotiating (?) methods which were not exactly on the Biblical and Religious Studies wavelength as discussed above. 
We have to admit, therefore, that Biblical Studies can no longer claim a place in public schools. This does not mean, however, that Biblical and Religious Studies is now destined to become part of the bygone history of the old South Africa. On the contrary, this remarkable field of study can indeed continue contributing to ongoing transformation in the new South Africa.

\section{Transforming the apparent end of an era into an enthusiastic continuation of meaningful activities}

An obvious first option, directly linked to the syllabus planning undertaken by the South African Biblical Studies Association since 1992, would be to design outlines for teachinglearning-sharing experiences among youngsters, adults and seniors in various contexts.

All the curricular expertise which has been developed in the field of Biblical and Religious Studies should encourage us to carry on drafting outlines and recommending guidelines, not only for private schools, but also for life-long learning among grown-ups and senior citizens. Even some ministers might benefit from such material!

A 1994 syllabus proposal, which was already designed in an outcomes-guided way, may provide an interesting example of what has been done and can still be done. The objectives were formulated as follows:

\section{Students should}

- understand as much as possible about the people of whom we read in the various parts of the Old and the New Testament: their life situations, faith experiences, and ways of believing and living,

- explore the ways in which the books of the Old and the New Testament came into being,

- focus special attention on the most appropriate ways of interpreting the literature types of the Old and the New Testament,

- explore the main emphases of the various religions in our present situation,

- develop an attitude of respecting and tolerating other religious convictions and their adherents,

- understand the far-reaching implications and powerful influence of Christian convictions and attitudes

(Syllabus drafting committee 1994:2).

A second option, of more informal nature, but possibly of wide-ranging influence, is to help create a climate in which the transformative insights of Biblical and Religious Studies are appreciated and promoted. Whatever might be done, in established churches and elsewhere, in order to disseminate and propagate the transformational influence discussed above, should indeed be done. The long-term task of helping to create such a climate, especially in environments where a different climate is still very much in place, will need benevolent understanding, faithful patience, tactful creativeness, and unrelenting commitment. But just imagine the transformative impact it could have!

A third option, which should never be neglected, is that of carrying on with quality research in the field of Biblical and Religious Studies. As more and more believers enjoy the benefits of such a salubrious and invigorating climate, researchers will increasingly be stimulated to intensify their research, and to present their findings in the form of writings, which are relevant for our time, as well as reader-friendly and appealing. And if there are 
larger numbers of possible readers it may make such material more appealing to publishers as well.

Nevertheless, however, whether we are encouraged by numbers and circumstances or not, let us remain committed to the Biblical and Religious Studies way of contextual understanding, which can show the way

- from a mere adherence to "truths of faith" to true believing as a life-changing reality,

- from incessant attempts to observe moral duties to spontaneously living a changed life,

- from religio-cultural separateness to mutually assertive co-existence.

Let me share two bits of experience as telling examples of the mindsets I am contrasting. In the congregation where we belong, a minister recently announced a hymn with the commendation that its wording focuses admirably on sin, salvation and gratitude. His catechetical line of thinking (fides quae!) reminded me of an unforgettable (fides quae and qua!) experience with regard to another hymn. That was when, walking down into the Grand Canyon on a Sunday morning, the huge silence was suddenly transformed into vocal praise as a choir sang "How great Thou art!" from Worship Point on the rim of the Canyon. In that remarkable context an intense faith relationship gave new and lasting meaning to a moving hymn.

And let me conclude with what I said in (the summary of) my inaugural lecture (Malan 1981:3) and am still wholeheartedly recommending:

The influence of foreign elements that have subtly infiltrated into Biblical interpretation... should be ...eliminated (where necessary)... or minimized (where that is sufficient)... Biblical Studies may (then) avail the opportunity thus created by paying due attention to relational studies.

After all, the crucial part of revelation is exactly the new relationship between God and man, ${ }^{47}$ opening up the possibility of a new quality of human living. It is not a matter of merely accepting truths of faith with the mind; the Christian believer is challenged to enter into and to live in relationships of faith.

In South Africa, where so much "Christian religion" is performed, without interrupting it (cf Matt. 5:23-24) to set right inter-personal and inter-group wrongs, this is a very special challenge to you and me.

Let us therefore yield ourselves to God, that He may transform us inwardly and bring about miracles of relationship - here and now.

And wherever the future will take each of us.

47. Apologies for the single-gendered wording! 


\section{BIBLIOGRAPHY}

Barr, David L 1987. New Testament Story: An Introduction. Belmont: Wadsworth.

Berger, Klaus 1988. Hermeneutik des Neuen Testaments (Hermeneutics of the New Testament). Gütersloh: Gütersloher Verlagshaus Gerd Mohn.

Berkhof, L 1967. Principles of Biblical Interpretation. Grand Rapids: Baker Book House.

Brunner, Peter 1925. Vom Glauben bei Calvin (About Calvin's View on Faith). Tübingen: JCB Mohr.

Constitutional Assembly 1996. Act 108 of 1996: The Constitution of the Republic of South Africa, 1996. (Cape Town: Constitutional Assembly.)

Du Toit, Ben 2000. God? Geloof in 'n postmoderne tyd (God? Faith in a post-modern era). Bloemfontein: CLF Uitgewers.

Duvenage, Schalk CW 1974. Bybelkunde as volwaardige vak op die middelbare skool (Biblical Studies as subject in its own right at Secondary School). Paper presented at Biblical Studies Conference, University of Port Elizabeth, 1974.

Ehrman, Bart D 1993. The Orthodox Corruption of Scripture: The Effect of Early Christological Controversies on the Text of the New Testament. Oxford: Oxford University Press.

Ehrman, Bart D 1995. The Text as Window: New Testament Manuscripts and the Social History of Early Christianity, in Ehrman, Bart D \& Holmes, Michael W (eds.), The Text of the New Testament in Contemporary Research: Essays on the Status Quaestionis (A Volume in Honor of Bruce M. Metzger). Grand Rapids: William B Eerdmans.

Grollenberg, Lucas 1979. A Bible for Our Time: Reading the Bible in the light of today's questions. London: SCM.

Gutbrod, Karl 1973. Kurze Bibelkunde des Neuen Testaments (Short Biblical Studies of the New Testament). Stuttgart: Calwer.

Kee, Howard C and Young, Franklin W 1987. The living world of the New Testament. London: Darton, Longman \& Todd.

Knap, JJ 1935. Van de Bekeering (About Conversion). Kampen: JH Kok.

Malan, JC 1981. Reduksie- en Relasiebybelkunde (Reductional and Relational Biblical Studies). Inaugural lecture, 20 March 1981. Bellville: University of the Western Cape.

Malan, Jannie 1997a. Faithless fear or fearless faith? Our orientation in a multi-religious context. Scriptura 60, 39-45.

Malan, Jannie 1997b. Meaningful outcomes, insights and undertakings. Hand-out at panel discussion and workshop on the School Syllabus during the 17th Annual Congress of the Southern African Biblical Studies Society, Johannesburg, 16-17 May 1997.

Malan, Jannie 1999. Study Guide for Religion, Conflict and Transformation (SBK 504). Port Elizabeth: University of Port Elizabeth.

Marsh, FE 1960. The structural principles of the Bible. London: Pickering \& Inglis.

Morris, Leon 1986. New Testament Theology. Grand Rapids: Academie Books, Zondervan.

Rossouw, Hendrik W 1963. Klaarheid en Interpretasie: Enkele probleemhistoriese gesigspunte in verband met die leer van die duidelikheid van die Heilige Skrif (Clearness and Interpretation: Some problem-historical viewpoints with regard to the doctrine of the clarity of Holy Scripture). Amsterdam: Jacob van Campen.

Sangster, WE 1957. The Secret of Radiant Life. London: Hodder \& Stoughton. 
Smart, James D 1970. The Strange Silence of the Bible in the Church: A study in hermeneutics. London: SCM Press.

Stewart, David 1980. Exploring the Philosophy of Religion. Englewood Cliffs: PrenticeHall.

Streeter, Burnett Hillman 1936. The God who speaks. London: Macmillan.

Syllabus drafting committee 1994. School syllabus proposals submitted by the syllabus drafting committee of the Southern African Biblical Studies Society. Hand-out at Annual General Meeting held during the 13th Annual Congress of the Southern African Biblical Studies Society, Pretoria, 27-28 May 1994.

Van Huyssteen, Wentzel 1986. Teologie as kritiese geloofsverantwoording (Theology as presenting a critical account of believing). Pretoria: Human Sciences Research Council. 